\title{
DIGITAL VALUE STREAM MAPPING USING THE TECNOMATIX PLANT SIMULATION SOFTWARE
}

\author{
Trebuna, . $^{*}$; Pekarcikova, M.* \& Edl, M.* \\ * Technical University in Kosice, Faculty of Mechanical Engineering, Institute of Management, \\ Industrial and Digital Engineering, Nemcovej 32, 04200 Kosice, Slovakia \\ ${ }^{* *}$ University of West Bohemia, Faculty of Mechanical Engineering, Department of Industrial \\ Engineering and Management, Univerzitni 8, 30100 Plzen, Czech Republic \\ E-Mail: peter.trebuna@tuke.sk,miriam.pekarcikova@tuke.sk, edl@kpv.zcu.cz
}

\begin{abstract}
Value Stream Mapping is a common and widely used method of industrial engineering. It creates a comprehensive overview of the possibilities of improving the production flow of the company as a whole and eliminates the introduction of incremental measures that would reduce the flexibility of the system as a whole. This article presents a method for optimizing material and information flows in a production company in the context of the Industry 4.0. The aim of the article is to emphasize the potential of software tools in synergy with the classical tool of lean manufacturing - Value Stream Mapping (VSM). For this purpose, the case study is focused on digital VSM in environment of the simulation software TX Plant Simulation. The transformation of the classical digital approach allows dynamic evaluations based on real discrete simulation of events and a simple evaluation of optimized variants.

(Received in June 2018, accepted in September 2018. This paper was with the authors 2 weeks for 2 revisions.)
\end{abstract}

Key Words: Value Stream Mapping, Simulation Software, Discrete Event Simulation, Value Added

\section{INTRODUCTION}

Value Stream Mapping is one of the basic tools of lean production concept focuses on the analysis of waste in the company. It allows visibility (using special type of flow chart with symbols known as "the language of Lean") and quantifies waste (examining the efficiency of processes known as "Value added index") in various processes. It is a combination of process and capacity model, inventory and flow management model. VSM is realized on the principle of physical flow mapping in real manufactory system, so called Gemba walk.

Rother and Shook deal with the Value Stream Mapping in their publication [1] with the practical implementation of this method and also define VSM as "a pencil and paper tool that helps you visualize and understand the flow of material and information as a product makes its way through its value stream." The authors proposed a procedure for drawing the current state map and also seven instructions to achieve optimal future status. When drawing maps of the current state, it is necessary to follow the following steps [1-6]: select a product family, collect the relevant data, incorporate the information flow, draw the timeline and interpret the current state map. In the terms of instructions, it is appropriate, according to the authors, to focus on: produce to takt time, use continuous flow and FIFO lanes, implemented Kanban supermarkets, production planning control through the pacemaker, levelling the product mix evenly, distribute the production volume evenly (in batch sizes), and production every part every day. Other authors dealing with VSM issues in various areas are presented in Table I.

Romero and Arce express in their study of applying VSM in production companies the opinion about the significant increase of interest on VSM in recent years. They highlight the need to adapt this technology to the needs and options according to the interests and needs of each particular case in industrial praxis [7]. Koch and Lödding present and specify in their work [8] more precisely the main differences in value streams mapping in conventional manufacture and make-to-order (MTO): 
1. Differences in logistic objectives - for MTO is the most important logistics target e.g., schedule reliability which has direct impact on delivery on time, for conventional VSM it is important to deal with WIP (work-in-progress, measured in number of parts) and throughput time. That is problem in companies with variable production, because material flow is more complex and the order contents are varying strongly.

2. Disagreement with the applied tasks of the manufacturing environment and manufacturing control - for MTO is not suitable guidelines which are accordance with the make-to-stock (MTS), e.g. in MTO tact time is highly fluctuating, FIFO is not acceptable because of chaotic sequencing, pacemaker is not efficient, because upstream processes should be decoupled by Kanban and it is impossible for MTO, levelling the product mix is problem. Fig. 1 presents a manufacturing control model which describes logistics approach to achieve the relevant objectives in manufacturing system. Model involves three control tasks like order release, capacity control and sequencing. One gap of conventional VSM is just capacity control, which ensures the schedule reliability, what it causes accumulate backlogs and inventory. The authors in [8] emphasize the need and effectiveness of a structured order release process, because it is a lever to control the work in progress and the throughput time in a MTO production.

Table I: Area of interest of VSM in research papers [2-10].

\begin{tabular}{|c|c|c|}
\hline Area of interest & Authors & Year \\
\hline \multirow[t]{2}{*}{ Theoretical research } & Hines and Rich & 2012 \\
\hline & Bhim Singh & 2009 \\
\hline \multirow[t]{3}{*}{ Industry } & Rother and Shook & 2003 \\
\hline & Womack and Jones & 2002 \\
\hline & Stadnicka and Antosz & 2013 \\
\hline \multirow[t]{2}{*}{ Mass production } & Belokar et al. & 2012 \\
\hline & Palak and Sheth & 2014 \\
\hline \multirow[t]{9}{*}{ Manufacturing processes } & Rahani and Al-Ashraf & 2012 \\
\hline & Jeyaray et al. & 2013 \\
\hline & Grewal & 2008 \\
\hline & Singh and Sharma & 2009 \\
\hline & Gunaki and Teli & 2015 \\
\hline & Venkataraman and Ramnath & 2014 \\
\hline & Lasa and Laburu & 2008 \\
\hline & Gurumurthy and Kodali & 2010 \\
\hline & Singh and Singh & 2013 \\
\hline \multirow[t]{3}{*}{ Assembly processes } & Kadam et al. & 2012 \\
\hline & Álvarez et al. & 2009 \\
\hline & Seth and Gupta & 2005 \\
\hline \multirow[t]{2}{*}{ Product development } & McManus and Millard & 2002 \\
\hline & Hugh et al. & 2002 \\
\hline \multirow[t]{2}{*}{ Business processes } & Teichgräber and de Bucourt & 2012 \\
\hline & Upadhye and Garg & 2013 \\
\hline $\begin{array}{l}\text { Administrative ones } \\
\end{array}$ & Chen and Cox & 2012 \\
\hline \multirow{2}{*}{$\begin{array}{r}\text { Simulations implementation together } \\
\text { with value stream analysis }\end{array}$} & Abdulmalek and Rajgopalb & 2007 \\
\hline & Chukukere et al. & 2014 \\
\hline
\end{tabular}

Creating a value flow graphically involves much less information about the production process than would be required. Information relating to the manufacturing process: cycle time, tact time, sequence of operation, lead time, production capacity, workload, working time, number of shifts, inventory and inputs data: order of customer, supply schedules are precisely defined to provide the information which is needed to analyse the current state and create a future map of the value flow [8-15]. 


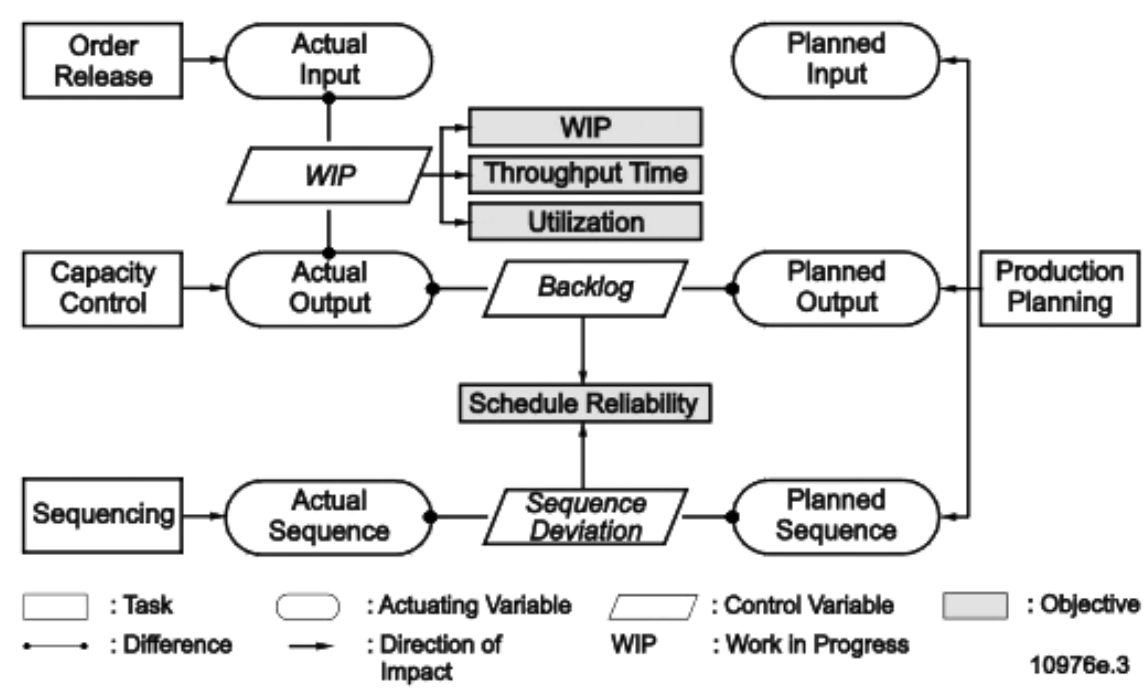

Figure 1: Manufacturing control model by Koch and Lödding [8].

\section{THE MODELLING METHODOLOGY OF VSM IN TX PLANT SIMULATION}

VSM simulation using the software handles all the necessary information while minimizing errors. It allows simulating different variants to the value flow control such push vs. pull system while increasing the value flow efficiency. The goal is not to eliminate such all waste, but to ensure the product to the customer as required, as quickly as possible and at the lowest cost. Conventional VSM process vs. digital VSM process is shown in Fig. 2 [8, 16-18].

Conventional VSM process
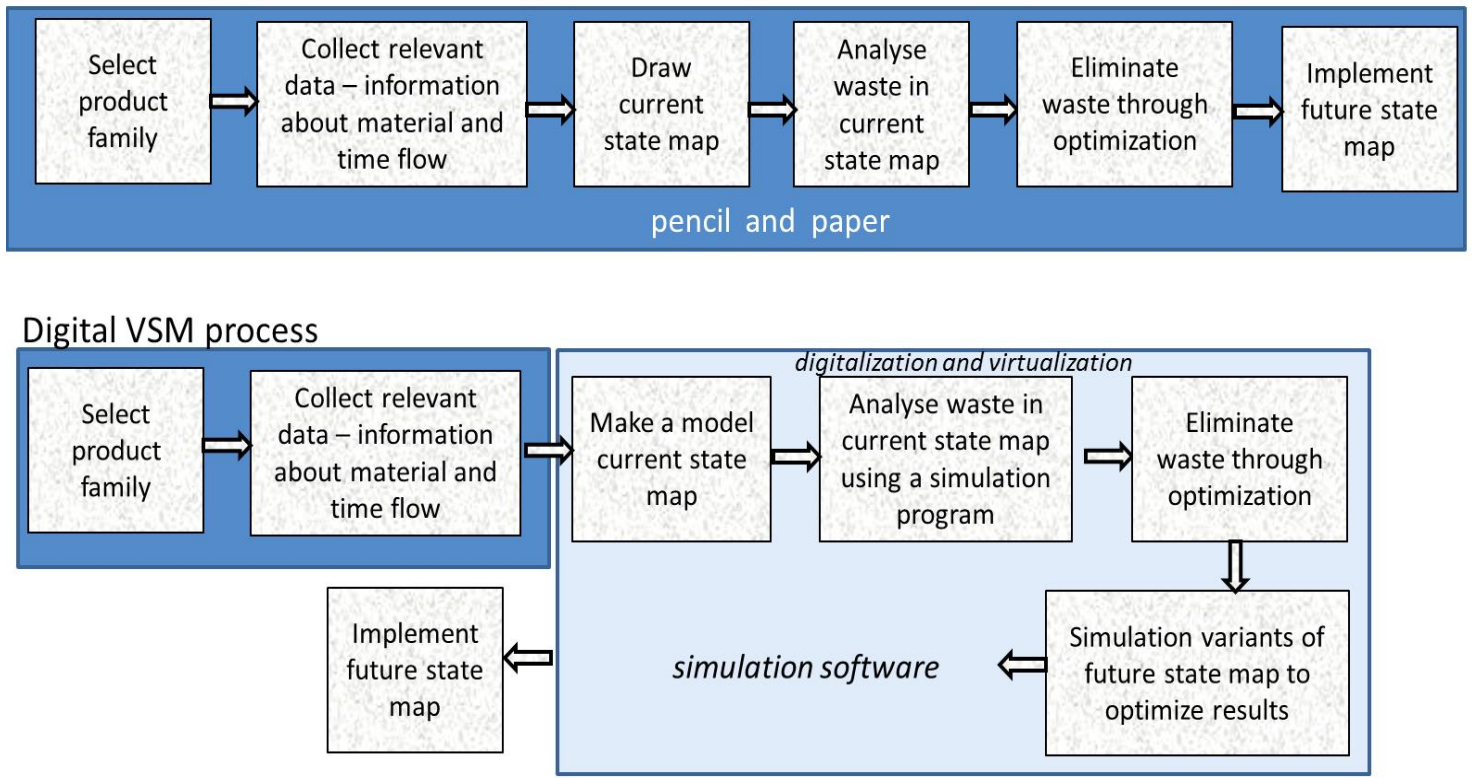

Figure 2: Conventional VSM process vs. digital VSM process [8, 16-18].

\subsection{Design of digital Value Stream Mapping}

Orientation on value should be the inherent part of the companies' strategies on a way to cumulate more customer value. Value for customer is a way to achieve success in business [13]. Logistic system is like a network with the stochastic and probabilistic nature. It consists of a finite number of active elements, which are the parts of logistics flows. Before the design 
of the simulation model, it is necessary to determine whether it is possible to design the model as a one system or a collection of several individual parts. Many types of simulation software allow designing the compendious hierarchic mutually synchronized network [19-23]. Simulation tools are more dynamic in terms of interactions between service levels and potential revenue generation [24].

\subsection{Digital Value Stream Mapping using Tecnomatix Plant Simulation}

Simulation software Tecnomatix Plant Simulation [25] is a discrete event simulation tool, which helps creating digital models of logistics systems such as manufacturing to test system performance and optimize performance. Discrete event simulation is a powerful tool for modelling complex dynamic systems. These digital models make it possible to create experiments and scenarios without disturbing existing production systems or using the planning process prior to installing genuine production systems. Extensive analysis tools, such as the analysis of barriers, statistics and graphs allow evaluating different manufacturing scenarios. The VSM Library is an optional add-on for Tecnomatix Plant Simulation.

The VSM Library takes into account the dynamic relationships of complex production sequences to increase the value-added production, variability, quality, speed and efficiency for increased production while reducing inventory and commitment of capital and securing supply in a timely manner. Traditionally, the production view is done manually and graphically by plotting the flow of values using paper sheet symbols that display conditions such as material flow, information flow, inventory, added value, and value-added activities.

Based on customer requirements, inventory, and cycle times, the analysis of the current state of production is performed by team. Revision and improvement of the flow of values are then derived from the flow mapping of the current values of the production process [26-28]. Value flow mapping is a standardized method based on generally accepted symbols. Main reasons to perform Value Mapping in simulation:

- reduce the cost of data collection by reducing the number of describing processes using predefined logic blocks,

- decrease the effort by analysing through automated modules.

With computer simulation it is possible to explore the dynamic flow effects of values which remain hidden in the static mapping of the value chain on paper in a case of conventional VSM. Traditional static value flow analysis is expanded to include a critical time element of stock availability. Simulation shows the dynamic fluctuations in daily production due to batch size, setting procedure, product changes, or other faults. The main output of VSM is the image representation of the flow of values and a comprehensive view of the production of the selected representative. Mapping provides a credible view of narrow production sites, the reasons for possible losses and inefficient production or storage systems. The main map outputs $[7,13,27,28]$ include:

- VA index (Value added index) - the added value of the manufacturing process or product to the total production runtime, expressed as a percentage,

- process time - primarily dependent on cycle time,

- work in progress - size, state,

- information on the amount of inventory.

\section{CASE STUDY}

The main objective of the case study was to create a dynamic model of map of the value stream in the production of the reference product and to optimize the current state in the TX Plant Simulation environment. The partial goal was to point out the possibilities that optimization through computer simulation allows. 


\subsection{Selection of product family using the $\mathrm{ABC}$ method}

The reference product in case study is steel cord, the main component used to reinforce the automobile tire. It is made of high carbon steel with high quality, testing and control requirements. The steel cord consists of four basic components as shown in Fig. 3 a, the cord structure is shown in Fig. 3 b.

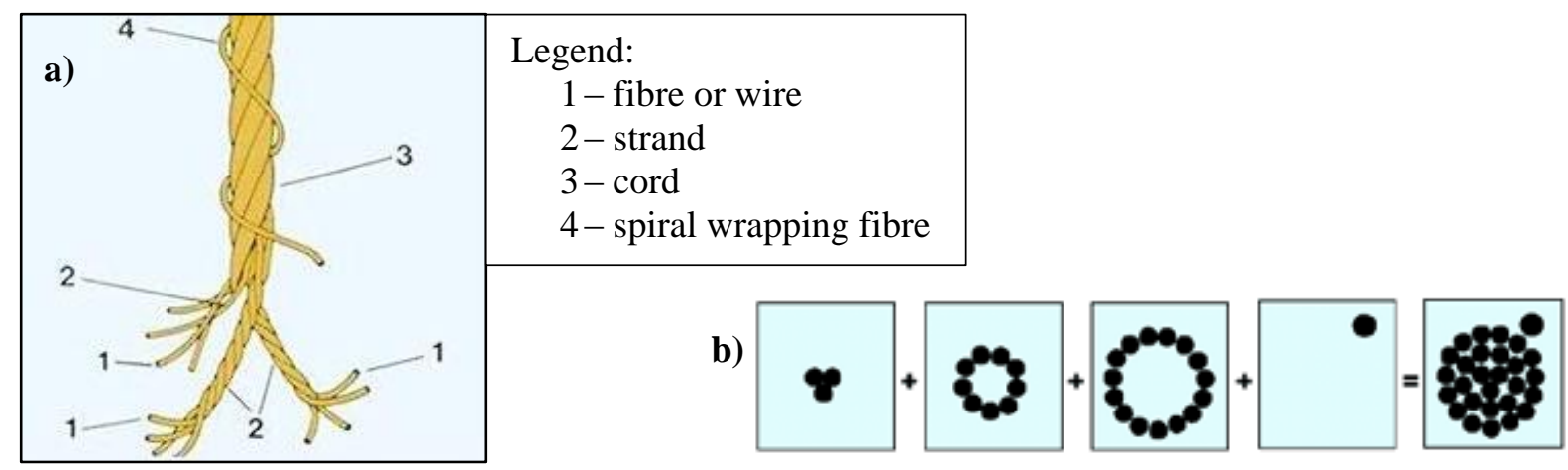

Figure 3: a) Composition of steel cord, b) structure of the cord [29].

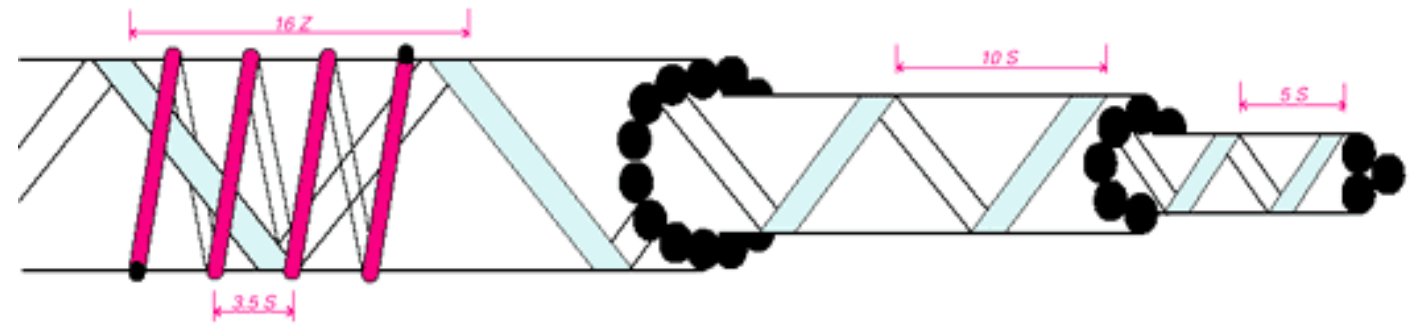

Figure 4: Length of fit and fit direction of fibre of cord [29].

\section{- Length of fit and fit direction of fibre of cord}

Rule: sequence or priority by labelling follows the sequence of production, i.e. starting with the innermost strand and gradually moving outwards (see Fig. 4).

Example: $(3+9+15) \times 0.22+0.15(5 / 10 / 16 / 3.5$ SSZS $)$

$5 \mathrm{~S}$ : length of fit and fit direction of strand, $3 \times 0.22$

$10 \mathrm{~S}$ : length of fit and fit direction of strand, $+9 \times 0.22$

$16 \mathrm{Z}$ : length of fit and fit direction of strand, $+15 \times 0.22$

$3.5 \mathrm{~S}$ : length of fit, fit direction of strand and fit direction of covering

Table II: Products division into family groups.

\begin{tabular}{|c|c|c|c|c|}
\hline Product & $\begin{array}{c}\text { Production } \\
\text { volume (tonnes) }\end{array}$ & $\begin{array}{c}\text { Production } \\
\text { volume cumulative } \\
\text { (tonnes) }\end{array}$ & $\begin{array}{c}\text { Cumulative \% of } \\
\text { total production }\end{array}$ & Classification \\
\hline $2+1 \times 0,30$ & 130 & 130 & $26 \%$ & $\mathrm{~A}$ \\
\hline $2+2 \times 0,28$ & 115 & 245 & $49 \%$ & $\mathrm{~A}$ \\
\hline $2 \times 0,30$ & 95 & 340 & $68 \%$ & $\mathrm{~A}$ \\
\hline $4 \times 0,28$ & 65 & 405 & $81 \%$ & $\mathrm{~A}$ \\
\hline $2+1 \times 0,28$ & 35 & 440 & $88 \%$ & $\mathrm{~B}$ \\
\hline $2 \times 0,30$ & 25 & 465 & $93 \%$ & $\mathrm{~B}$ \\
\hline $2+1 \times 0,26$ & 15 & 480 & $96 \%$ & $\mathrm{~B}$ \\
\hline $2+2 \times 0,25$ & 10 & 490 & $98 \%$ & $\mathrm{C}$ \\
\hline $4 \times 0,22$ & 5 & 495 & $99 \%$ & $\mathrm{C}$ \\
\hline $5 \times 0,25$ OPEN & 5 & 500 & $100 \%$ & $\mathrm{C}$ \\
\hline
\end{tabular}


The ABC analysis [30] will be done based the volume of production in tonnes per product. Table II lists the products with a monthly production volume. It is clear, from the results, that the most monitored products group include the products: $2+1 \times 0,30,2+2 \times 0,28$, $2 \times 0,30$ and $4 \times 0,28$. These four products have the highest priority and therefore the value flow analysis will be focused on these key products.

\subsection{Dynamic model of current state map}

To compile a map of the current state, it is necessary to monitor the material flow directly in the production. It starts at an expedition where inventory levels have been evaluated and further information is collected between the warehouse stock and between the processes towards the material input from the supplier. To compile a current state map, it is necessary to work with data that is as up-to-date as possible. In Fig. 5 a schematic diagram of operations and in-process stores in production is shown. Scheme presents the exact sequence of product flow in processes as well as between in-process stores.

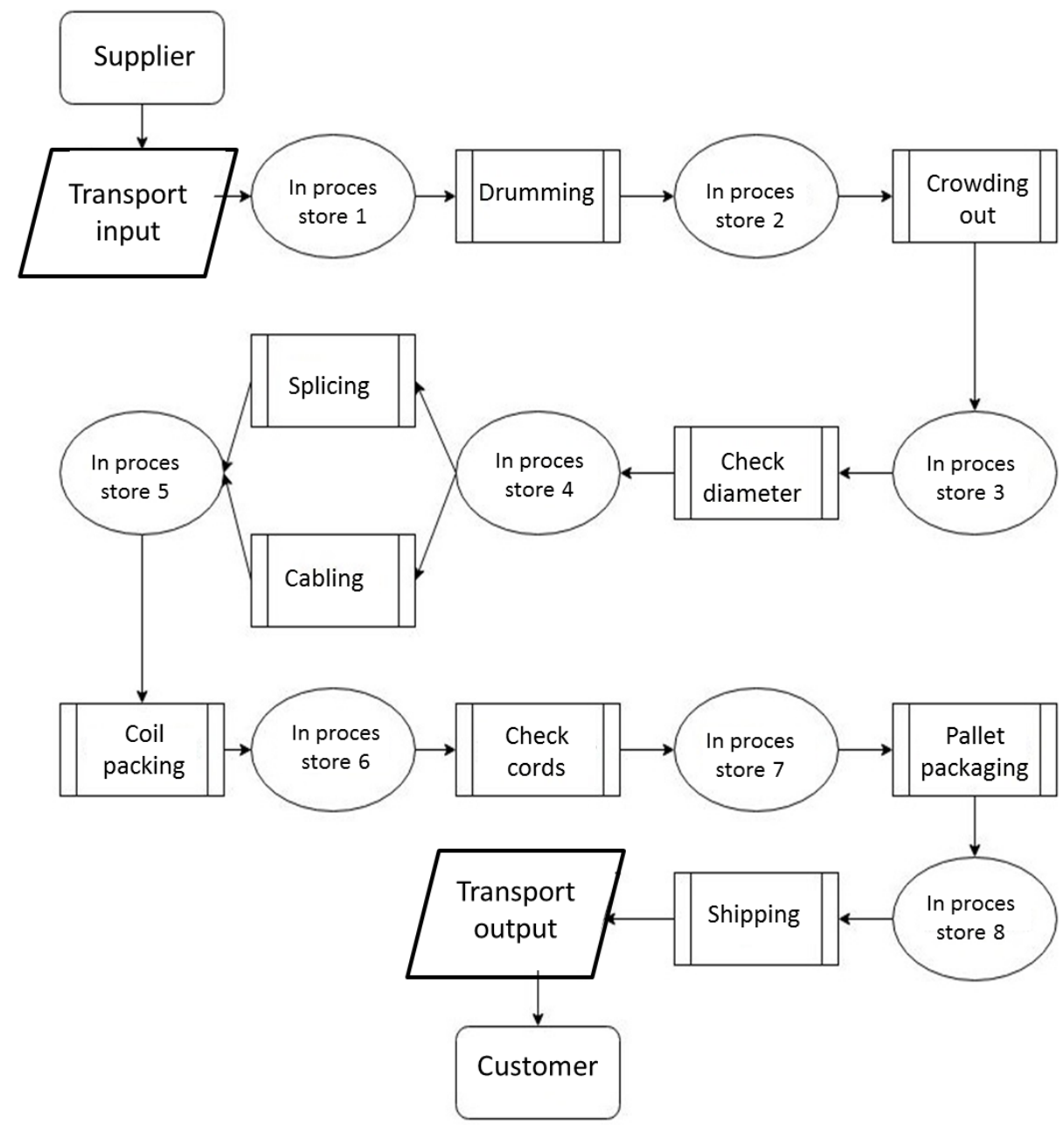

Figure 5: Schematic diagram of production process.

In Table III are processed the input information of manufacturing process, equipment and production times of operations during the production of the GDI pump.

The current state map presents information about operations, cycle times, total device efficiency, and also describes the results of the continuous production time, value added index, number of process steps and number of finished pieces in WIP and in expedition store. When creating a VSM, it is necessary to focus not only on mapping the value flow but also on 
the flow of information. At the top of the current map, production planning and management, material suppliers, and customer are shown. In the next section, individual operations and warehouses are shown. In Fig. 6 is a simulated current state model of VSM, where objects in this model copy the sequence of the machine fleet and the storage space. Information of utilization of all processes and the in-process store in simulation are in Fig. 7 and in Table IV.

Table III: Input information of manufacturing process.

\begin{tabular}{|l|c|c|c|c|}
\hline \multicolumn{1}{|c|}{ Process } & $\begin{array}{c}\text { Cycle time } \\
\text { (DDD:HH:MM:SS.XXX) }\end{array}$ & $\begin{array}{c}\text { Set-up time } \\
\text { (MM:SS.XXX) }\end{array}$ & $\begin{array}{c}\text { Availability } \\
(\%)\end{array}$ & $\begin{array}{c}\text { MTTR } \\
\text { (MM:SS.XXX) }\end{array}$ \\
\hline Drumming & $1: 15: 00$ & $0: 00.0000$ & 100 & 0.0000 \\
\hline Crowding out & $4: 40: 00-4: 55: 00$ & $10: 00.0000$ & 95 & $5: 00.0000$ \\
\hline Checking the diameter & $2: 00$ & $0: 00.0000$ & 100 & 0.0000 \\
\hline Cabling & $3: 10: 00-3: 20: 00$ & $10: 00.0000$ & 95 & $5: 00.0000$ \\
\hline Splicing & $2: 15: 00-2: 25: 00$ & $10: 00.0000$ & 95 & $5: 00.0000$ \\
\hline Coil packing & $6: 00$ & $0: 00.0000$ & 100 & 0.0000 \\
\hline Check cords & $11: 00$ & $0: 00.0000$ & 100 & 0.0000 \\
\hline Pallet packaging & $9: 00$ & $0: 00.0000$ & 100 & 0.0000 \\
\hline Shipping & $15: 00$ & $0: 00.0000$ & 100 & 0.0000 \\
\hline
\end{tabular}

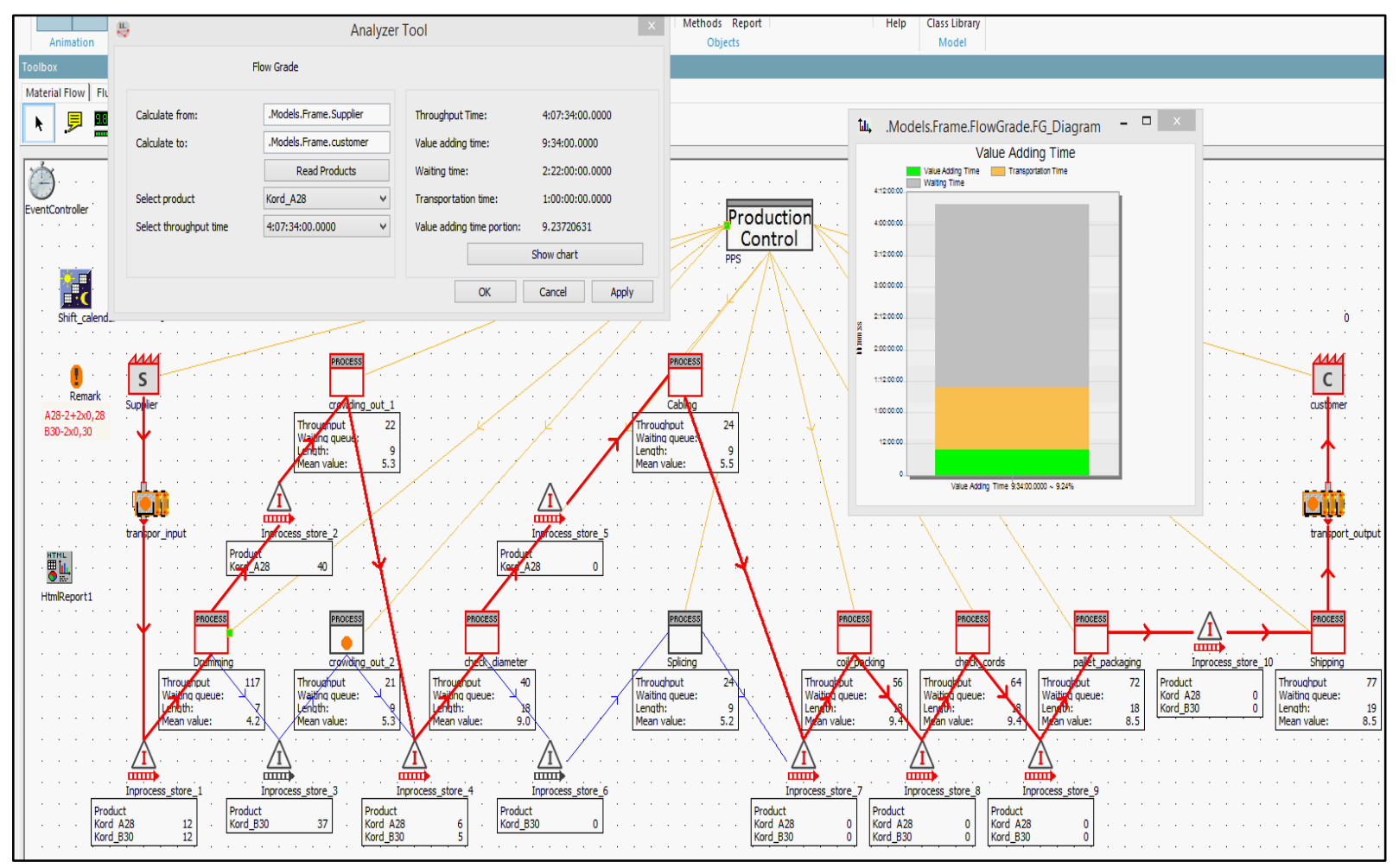

Figure 6: Current state map with the highlighted path of production lead time for product A30$2+1 \times 0,30$.

The added value index $(V A i)$ is a reference factor that reflects the percentage share of times of process steps of value-adding in proportion to the lead time. The simulation results for all four products are processed in Table V. 


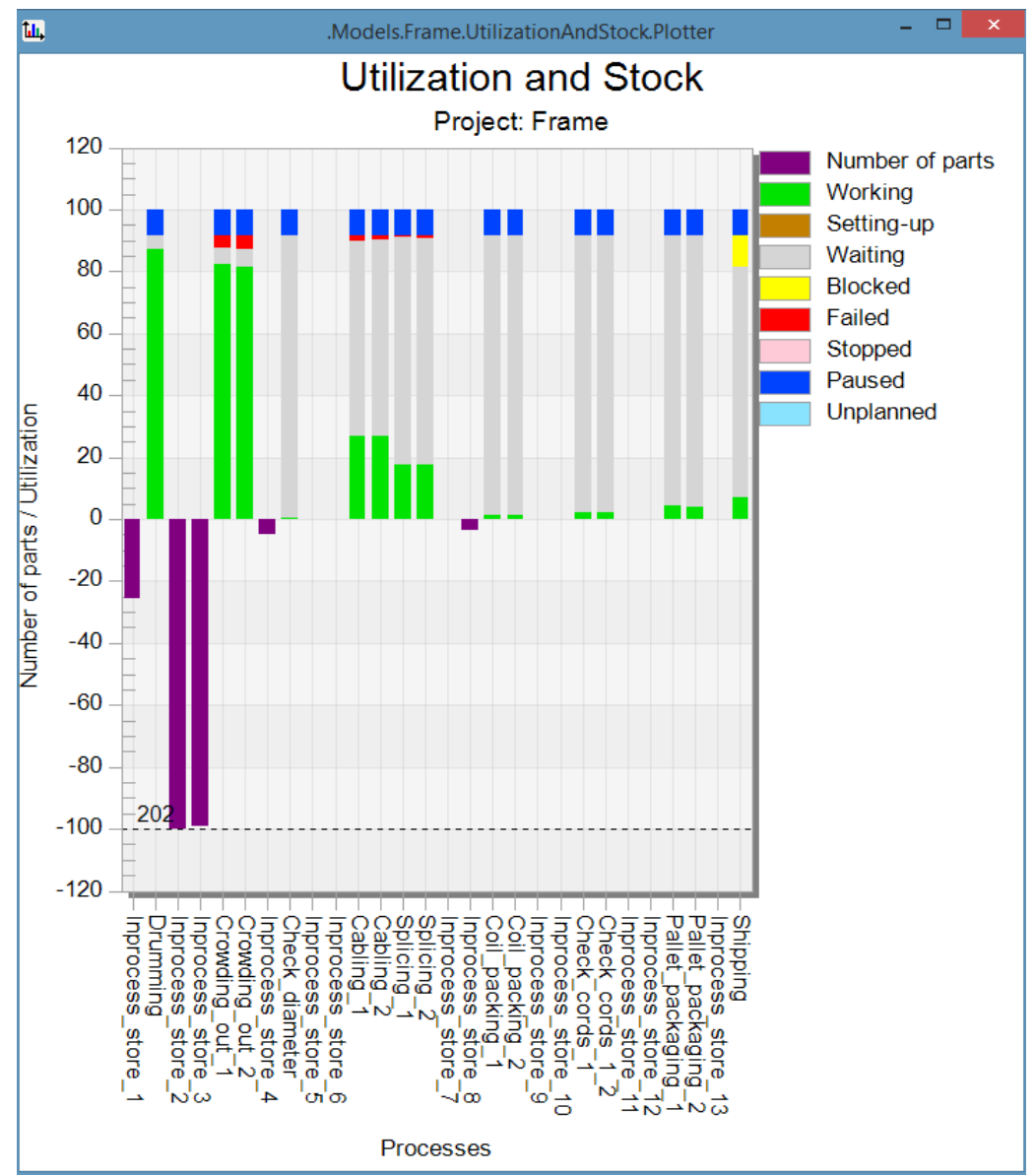

\begin{tabular}{|c|c|c|c|}
\hline \multicolumn{4}{|c|}{.Models.Frame.WIP.WIP } \\
\hline \multicolumn{4}{|c|}{292} \\
\hline & Object/Product & Kord_D28 & Kord_A30 \\
\hline 1 & Supplier & 292 & 0 \\
\hline 2 & Transport_input & 64 & 0 \\
\hline 3 & Transport_output & 7 & \\
\hline 4 & Inprocess_store_1 & 12 & 12 \\
\hline 5 & Drumming & & 1 \\
\hline 6 & Crowding_out_1 & & 1 \\
\hline 7 & Inprocess_store_4 & 0 & 5 \\
\hline 8 & Inprocess_store_3 & 104 & \\
\hline 9 & Splicing_1 & & \\
\hline 10 & Splicing_2 & & \\
\hline 11 & Cabling_1 & & \\
\hline 12 & Cabling_2 & & \\
\hline 13 & Check_diameter & & \\
\hline 14 & Inprocess_store_6 & 0 & \\
\hline 15 & Coil_packing_1 & & \\
\hline 16 & Check_cords_1 & & \\
\hline 17 & Pallet_packaging_1 & & \\
\hline 18 & Shipping & & 1 \\
\hline 19 & Crowding_out_2 & & \\
\hline 20 & Coil_packing_2 & & \\
\hline 21 & Check_cords_1_2 & & \\
\hline 22 & Pallet_packaging_2 & & \\
\hline 23 & Inprocess_store_7 & & 0 \\
\hline 24 & Inprocess_store_8 & 0 & \\
\hline 25 & Inprocess_store_9 & & 0 \\
\hline 26 & Inprocess_store_10 & 0 & \\
\hline 27 & Inprocess_store_11 & & 0 \\
\hline 28 & Inprocess_store_12 & 0 & \\
\hline 29 & Inprocess_store_2 & & 98 \\
\hline 30 & Inprocess_store_13 & 0 & 6 \\
\hline 31 & Inprocess_store_5 & & 0 \\
\hline 32 & Total: & 479 & 124 \\
\hline
\end{tabular}

Figure 7: Chart of utilization of all processes and the in-process store in simulation (left); current work in process - part of list (right).

Table IV: Table of utilization of all processes and the in-process store in simulation.

\begin{tabular}{|c|r|r|r|r|r|r|r|r|r|c|}
\hline Object & Working & Set-up & Waiting & Blocked & Powering up/down & Failed & Stopped & Paused & Unplanned & Portion \\
\hline Customer & $0.00 \%$ & $0.00 \%$ & $100.00 \%$ & $0.00 \%$ & $0.00 \%$ & $0.00 \%$ & $0.00 \%$ & $0.00 \%$ & $0.00 \%$ & \\
\hline Supplier & $0.00 \%$ & $0.00 \%$ & $100.00 \%$ & $0.00 \%$ & $0.00 \%$ & $0.00 \%$ & $0.00 \%$ & $0.00 \%$ & $0.00 \%$ & \\
\hline Drumming & $87.08 \%$ & $0.00 \%$ & $4.58 \%$ & $0.00 \%$ & $0.00 \%$ & $0.00 \%$ & $0.00 \%$ & $8.33 \%$ & $0.00 \%$ & \\
\hline Crowding_out_1 & $82.18 \%$ & $0.35 \%$ & $5.14 \%$ & $0.00 \%$ & $0.00 \%$ & $4.00 \%$ & $0.00 \%$ & $8.33 \%$ & $0.00 \%$ & \\
\hline Splicing_1 & $17.78 \%$ & $0.02 \%$ & $73.14 \%$ & $0.00 \%$ & $0.00 \%$ & $0.72 \%$ & $0.00 \%$ & $8.33 \%$ & $0.00 \%$ & \\
\hline Splicing_2 & $17.78 \%$ & $0.02 \%$ & $72.87 \%$ & $0.00 \%$ & $0.00 \%$ & $0.99 \%$ & $0.00 \%$ & $8.33 \%$ & $0.00 \%$ & \\
\hline Cabling_1 & $26.67 \%$ & $0.02 \%$ & $63.31 \%$ & $0.00 \%$ & $0.00 \%$ & $1.67 \%$ & $0.00 \%$ & $8.33 \%$ & $0.00 \%$ & \\
\hline Cabling_2 & $26.67 \%$ & $0.02 \%$ & $63.55 \%$ & $0.00 \%$ & $0.00 \%$ & $1.43 \%$ & $0.00 \%$ & $8.33 \%$ & $0.00 \%$ & \\
\hline Check_diameter & $0.56 \%$ & $0.00 \%$ & $91.11 \%$ & $0.00 \%$ & $0.00 \%$ & $0.00 \%$ & $0.00 \%$ & $8.33 \%$ & $0.00 \%$ & \\
\hline Coil_packing_1 & $1.26 \%$ & $0.00 \%$ & $90.41 \%$ & $0.00 \%$ & $0.00 \%$ & $0.00 \%$ & $0.00 \%$ & $8.33 \%$ & $0.00 \%$ & \\
\hline Check_cords_1 & $2.33 \%$ & $0.00 \%$ & $89.33 \%$ & $0.00 \%$ & $0.00 \%$ & $0.00 \%$ & $0.00 \%$ & $8.33 \%$ & $0.00 \%$ & \\
\hline Pallet_packaging_1 & $4.22 \%$ & $0.00 \%$ & $87.44 \%$ & $0.00 \%$ & $0.00 \%$ & $0.00 \%$ & $0.00 \%$ & $8.33 \%$ & $0.00 \%$ & \\
\hline Shipping & $7.05 \%$ & $0.00 \%$ & $74.26 \%$ & $10.36 \%$ & $0.00 \%$ & $0.00 \%$ & $0.00 \%$ & $8.33 \%$ & $0.00 \%$ & $\mathbf{\square}$ \\
\hline Crowding_out_2 & $81.29 \%$ & $0.35 \%$ & $5.69 \%$ & $0.00 \%$ & $0.00 \%$ & $4.34 \%$ & $0.00 \%$ & $8.33 \%$ & $0.00 \%$ & $\mathbf{\square}$ \\
\hline Coil_packing_2 & $1.19 \%$ & $0.00 \%$ & $90.48 \%$ & $0.00 \%$ & $0.00 \%$ & $0.00 \%$ & $0.00 \%$ & $8.33 \%$ & $0.00 \%$ & $\mathbf{\square}$ \\
\hline Check_cords_1_2 & $2.20 \%$ & $0.00 \%$ & $89.46 \%$ & $0.00 \%$ & $0.00 \%$ & $0.00 \%$ & $0.00 \%$ & $8.33 \%$ & $0.00 \%$ & $\mathbf{\square}$ \\
\hline Pallet_packaging_2 & $4.00 \%$ & $0.00 \%$ & $87.67 \%$ & $0.00 \%$ & $0.00 \%$ & $0.00 \%$ & $0.00 \%$ & $8.33 \%$ & $0.00 \%$ & $\mathbf{\square}$ \\
\hline
\end{tabular}

Portions of the States 
Table V: Simulation results of the lead time and value added index for all products.

\begin{tabular}{|c|c|c|}
\hline Product & $\begin{array}{c}\text { The added value index } \\
\boldsymbol{V} \boldsymbol{A i}\end{array}$ & $\begin{array}{c}\text { Lead time } \boldsymbol{P D} \boldsymbol{V} \\
(\text { days })\end{array}$ \\
\hline $\mathrm{A} 30-2+1 \times 0,30$ & $5,47 \%$ & 7,2451 \\
\hline $\mathrm{B} 28-2+2 \times 0,28$ & $5,59 \%$ & 7,3910 \\
\hline C $30-2 \times 0,30$ & $4,82 \%$ & 7,4326 \\
\hline $\mathrm{D} 28-4 \times 0,28$ & $5,45 \%$ & 6,8951 \\
\hline
\end{tabular}

The number of process steps ( $P P K s)$ is 8 for the production of mapped products. Of these, the number of process steps with the value added (PKVAi) is 6 , and the number of process steps without added value ( $P K N V A i)$ is 2 , i.e. $75 \%$ of the added value steps.

\subsection{Evaluate current state of simulation data}

The output of modelling and simulation of a current state map is graphical model of the whole process with all the necessary data about the production itself. By processing a current state map, basic data and visualization of the bottlenecks of the Crowding_out_1 and Crowding_out_2 processes were found. Also the percentages of work and waiting time for individual processes and the production lead time for all products, the index of added value, the number of process steps and other essential data for the design and creation of various variants of the map of the future state. After analysing the current state, it was found that there are Crowding_out_1 and Crowding_out_2 processes where the problem arises and needs to be solved. These bottlenecks in production process are inefficient and wasteful, and it is necessary to focus on these bottlenecks. Recognition of problems and their subsequent solution will help to optimize the production flow and also increase customer value. When the required material is placed into In-process_store_1, it causes too long waiting for the production process. Too long waiting for processing is also in In-process_store_2 and Inprocess_store_3. Exerted weekly planning will need to be broken down into daily planning, because it is inadequate. It is necessary to ensure the functioning of more efficient daytime planning also by introducing the Kanban system.

\subsection{Proposal variants of future state in Tecnomatix Plant Simulation}

Two variants were suggested. The first Variant A uses a single Kanban system in the production simulation. The second Variant B uses up to three Kanban systems in production simulation. When designing new workspaces, supermarkets and FIFOs were used instead of warehouses and to change the system from push to pull it was implemented Kanban card system. Implementation of Kanban system brings reduction in stored stocks and the elimination of downtime. The weakest elements of the production process were identified: Crowding_out_1 and Crowding_out_2. Kanban cards based on the pull principle ensured the smooth material flow. With deployment of Kanban cards, the production stations are more interconnected because the Kanban system operates on the principle of transmitting the Kanban signal from the last workstation and always sends a signal that the workstation can accept the semi-product. With Kanban cards the information flow and workplace communication is more efficient. The simulation was set to 30 days, after the simulation run, it is possible to compare the results of Variant A and Variant B and evaluate them (see Figs. 8 and 9). 


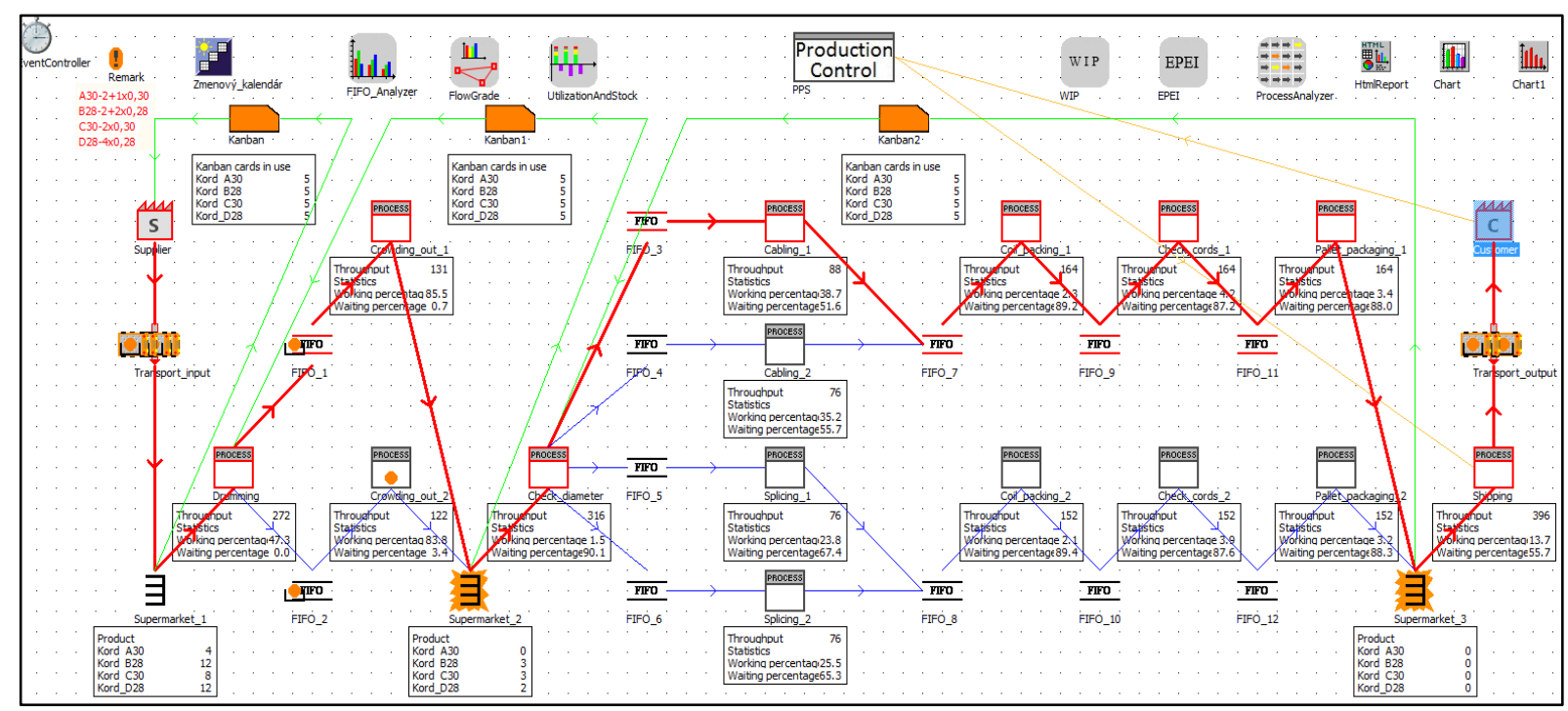

Figure 8: Future state map - variant A.

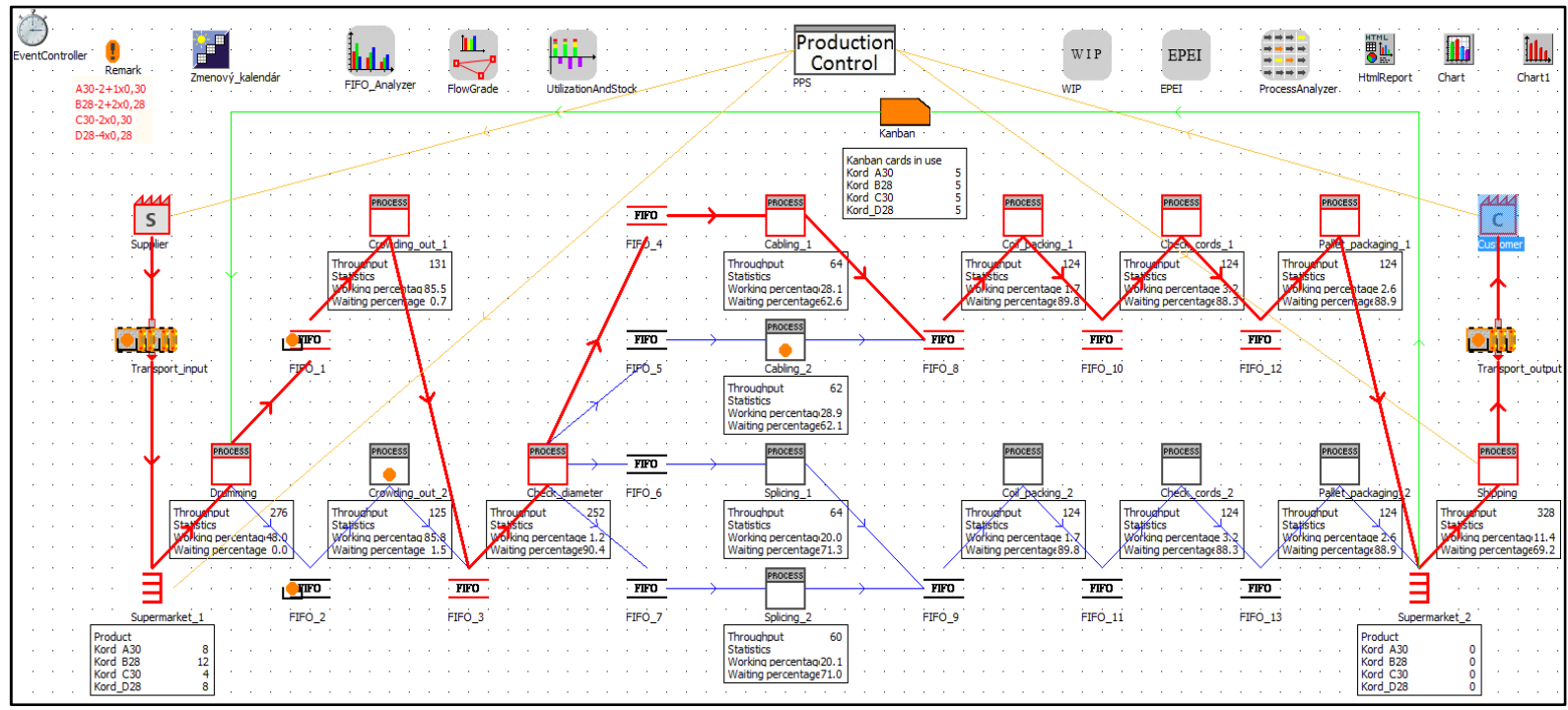

Figure 9: Future state map - variant B.

Comparing the variants A and B the following parameters were observed: the highest average value of the production lead time, the highest average value added index, the lowest average stock of products. The production lead time for product A30- $2+1 \times 0.30$ (see Figs. 8 and 9) shows that visually after simulation the path from the supplier to the customer is the same in both variants. The product transition after the pull operation is changed, i.e. the product in variant A passes through the FIFO area directly without delay for the next diameter control process. In variant B product is temporarily stored in the supermarket and is selected from it until the arrival of the Kanban card.

There is also a difference in material input from supplier to production. Supermarket 1 in option A receives information from PPS production management, and in variant B, supermarket 1 is controlled by the Kanban card system. The productions lead time (see Figs. 10 and 11) informs about product $\mathrm{A} 30-2+1 \times 0.30$ for $\mathrm{A}$ and $\mathrm{B}$ variants. The difference between the variants for this product is 0.1945 days. The others products are shown in Table VI. It can be deduced that variant $\mathrm{A}$ is more advantageous for three products than variant $\mathrm{B}$ which is more advantageous for one product only. 


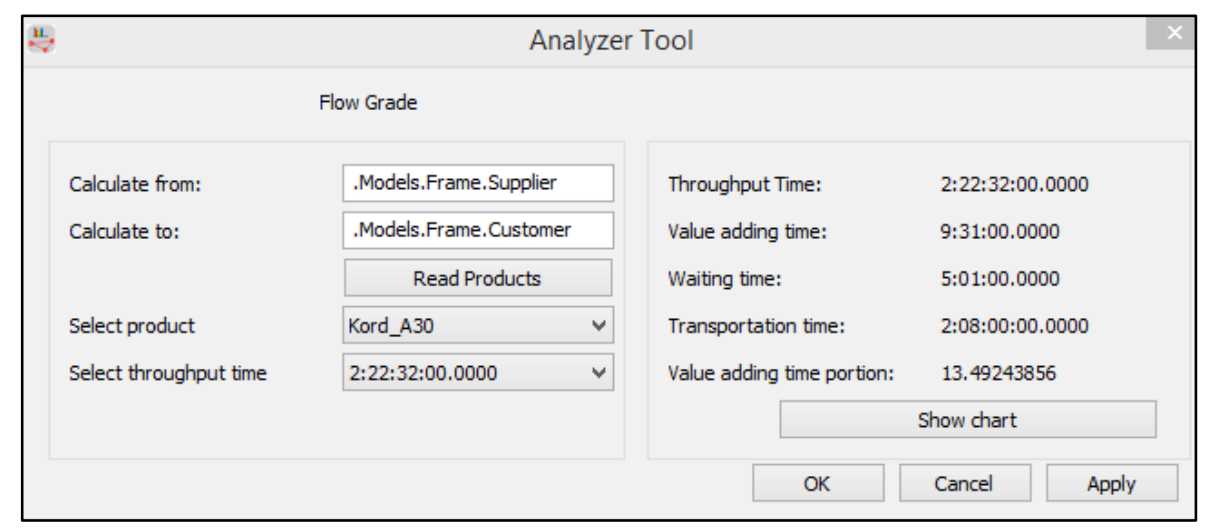

Figure 10: Production lead times for product A30-2+1×0,30, variant A.

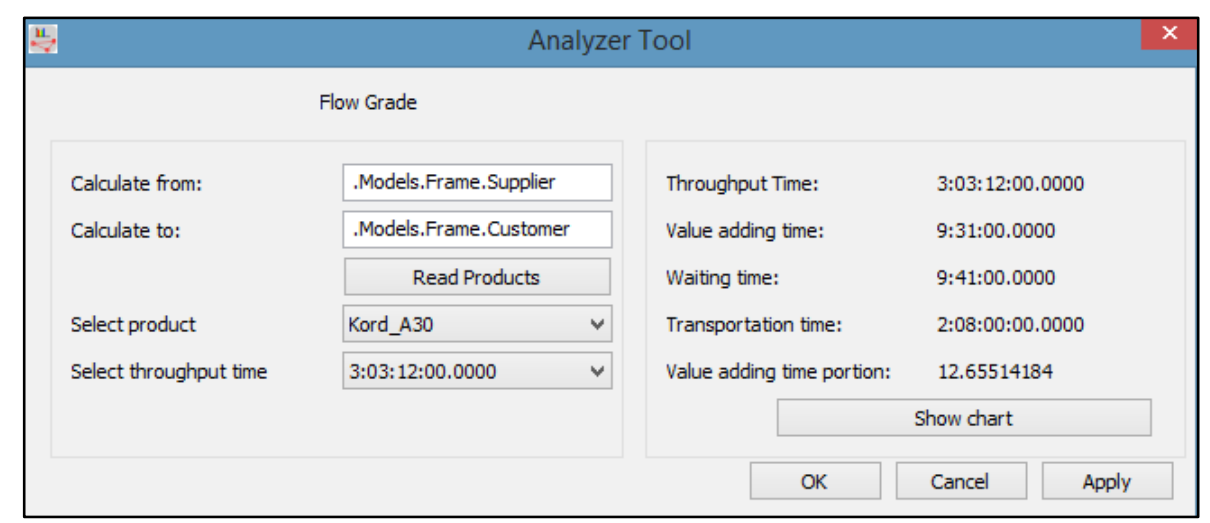

Figure 11: Production lead times for product A30-2+1×0,30, variant $\mathrm{B}$.

Table VI: Results from all simulations of the production lead time for all products and current state.

\begin{tabular}{|c|c|c|c|c|c|}
\hline \multirow[b]{2}{*}{ Product } & \multicolumn{5}{|c|}{ Production lead time for all products (days) } \\
\hline & $\begin{array}{c}\text { Future state } \\
\text { Variant A }\end{array}$ & $\begin{array}{c}\text { Future state } \\
\text { Variant B }\end{array}$ & $\begin{array}{l}\text { Difference } \\
\text { (best) }\end{array}$ & $\begin{array}{c}\text { Current } \\
\text { state }(\mathrm{CS})\end{array}$ & $\begin{array}{c}\text { Difference } \\
(\mathrm{CS}-\text { Variant } \mathrm{A})\end{array}$ \\
\hline A $30-2+1 \times 0,30$ & 3,1333 & 2,9388 & $0,1945(\mathrm{~B})$ & 7,2451 & 4,1118 \\
\hline B $28-2+2 \times 0,28$ & 3,1680 & 3,5777 & $0,4097(\mathrm{~A})$ & 7,3910 & 4,2230 \\
\hline C $30-2 \times 0,30$ & 3,0569 & 3,4458 & $0,3889(\mathrm{~A})$ & 7,4326 & 4,3757 \\
\hline D28-4×0,28 & 3,0916 & 3,2965 & 0,2049 (A) & 6,8951 & 3,8035 \\
\hline
\end{tabular}

Table VII: Results from all simulations of the VAi for all products and current state.

\begin{tabular}{|c|c|c|c|c|c|}
\hline \multirow[b]{2}{*}{ Product } & \multicolumn{5}{|c|}{ Value added index for all products } \\
\hline & $\begin{array}{c}\text { Future state } \\
\text { Variant A }\end{array}$ & $\begin{array}{c}\text { Future state } \\
\text { Variant B }\end{array}$ & $\begin{array}{c}\text { Difference } \\
\text { (best) }\end{array}$ & $\begin{array}{c}\text { Current } \\
\text { state }(\mathrm{CS})\end{array}$ & $\begin{array}{c}\text { Difference } \\
(\text { Variant A - CS })\end{array}$ \\
\hline $\mathrm{A} 30-2+1 \times 0,30$ & $12,66 \%$ & $13,49 \%$ & $0,83 \%(\mathrm{~B})$ & $5,47 \%$ & $7,19 \%$ \\
\hline B $28-2+2 \times 0,28$ & $13,06 \%$ & $11,57 \%$ & $1,49 \%(\mathrm{~A})$ & $5,59 \%$ & $7,47 \%$ \\
\hline $\mathrm{C} 30-2 \times 0,30$ & $11,72 \%$ & $10,40 \%$ & $1,32 \%(\mathrm{~A})$ & $4,82 \%$ & $6,90 \%$ \\
\hline D28-4×0,28 & $12,15 \%$ & $11,40 \%$ & $0,75 \%(\mathrm{~A})$ & $5,45 \%$ & $6,70 \%$ \\
\hline
\end{tabular}

The added value index for variants $\mathrm{A}$ and $\mathrm{B}$, and the differences between the products are summarized in Table VII. Variant A is more advantageous in three products than Option B, which is more convenient for one product only. 
Utilization of supermarkets for variant A and variant B after 30 days: max. inventories are approx. $19-20$ pieces for each product. Minimum inventories are not. Average inventory for variant $A$ are at a level of 2 to 3 pieces for each product. The average inventory for variant $B$ is at the level of 7 pieces for each product. Variant A has lower inventories and is therefore even more advantageous in terms of volume of space required for storage. This suggests that the more appropriate option for implementation in the enterprise is variant A. This is partly due to the proposal of simulation, when variant A has two supermarkets with initial stocks of 20 pieces of products, and variant B has three supermarkets with initial stocks of 20 pieces of products. There are also a variety of Kanban systems used, one for variant A and three for variant $\mathrm{B}$. The material and information flow became smoother using the Kanban system and shortened the waiting time in the warehouse. This has resulted in a streamlining of processes and resources between the supplier and the customer. If simulation continued for a longer period of time (more than a month), larger differences between variant A and variant B could be seen.

\section{CONCLUSION AND OUTLOOK}

The transformation of the conventional VSM method into digital form through the selected TX Plant Simulation software tool has led to concrete results for the company. Production will be more flexible and capable of responding to new situations and solving them immediately. There will be no slowdown in the production process. This will help team to correct weekly planning that will become more accurate. Also, control feedback will be an essential element to help preventing deviations in production. By introducing Kanban cards the inventory work in progress and finished goods will be reduced, as currently lying as semifinished and finished products for a long time in stock. When comparing the present state with variant A of the future state, shown in Table VI and Table VII, it can be concluded that the production lead time decreased on average from 7,2409 days to 3,1124 days, which is the difference of 4,1285 days. Value added index increased by an average from $5.33 \%$ to $12.40 \%$, which is a $7.07 \%$ difference. Inventories have been reduced from the current 27 pieces of products per one type to 8 pieces of products per type. This means saving space for 19 pieces of products per type. The new draft state of the future brings a significant reduction in average production time (on average by about 4 days) and increases the value added index by an average of about $7 \%$. Also, input inventories were reduced by 19 pieces of products per type.

The use of this methodology is particularly suitable for medium to high series production (high-volume low-mix), since variability and parallel material flows have a negative impact on the efficiency of its use. Currently, it is necessary to eliminate these limitations with regard to product customization, respectively to direction of production (Make-to-Order), thereby expanding the scope of its applicability.

In the context of Industry 4.0 and increasing the competitive environment, requirements for the analysing process and for designing the value flows also increase. An important element in the conventional VSM methodology is the area of capacity control that directly affects the performance of the production system. Processed case study points to the need for VSM digitization and simulation of value flows in the selected simulation program, which can help in the complex analysis and design of the future solution. The potential of digital VSM will be fully exploited only when the digital enterprise is fully implemented, i.e. after applications such as CPS/Cyber Physical System, IoT/Internet of Things etc., which enable creating networks and communication between the elements and units and collecting and processing data in real-time such as Big Data, Cloud Computing. 


\section{ACKNOWLEDGEMENT}

This article was created by implementation of the grant project VEGA 1/0708/16 "Development of new research methods for simulation, assessment, evaluation and quantification of advanced methods of production", KEGA 030TUKE-4/2017 "Implementation of innovative instruments for increasing the quality of higher education in the 5.2.52 Industrial Engineering field of study" and APVV-17-0258 "Digital engineering elements application in innovation and optimization of production flows".

\section{REFERENCES}

[1] Rother, M.; Shook, J. (2003). Learning to See: Value Stream Mapping to Create Value and Eliminate Muda, Version 1.3, The Lean Enterprise Institute, Cambridge

[2] Antonelli, D.; Stadnicka, D. (2018). Combining factory simulation with value stream mapping: a critical discussion, Procedia CIRP, Vol. 67, 30-35, doi:10.1016/j.procir.2017.12.171

[3] Deshkar, A.; Kamle, S.; Giri, J.; Korde, V. (2018). Design and evaluation of a Lean Manufacturing framework using Value Stream Mapping (VSM) for a plastic bag manufacturing unit, Materials Today: Proceedings, Vol. 5, No. 2, 7668-7677, doi:10.1016/j.matpr.2017.11.442

[4] Bin Ali, N.; Petersen, K.; Schneider, K. (2016). FLOW-assisted value stream mapping in the early phases of large-scale software development, Journal of Systems and Software, Vol. 111, 213-227, doi:10.1016/j.jss.2015.10.013

[5] Lehocká, D.; Hlavatý, I.; Hloch, S. (2016). Rationalization of material flow in production of semitrailer frame for automotive industry, Technical Gazette, Vol. 23, No. 4, 1215-1220, doi:10.17559/TV-20131113100109

[6] Haefner, B.; Kraemer, A.; Stauss, T.; Lanza, G. (2014). Quality Value Stream Mapping, Procedia CIRP, Vol. 17, 254-259, doi:10.1016/j.procir.2014.01.093

[7] Romero, L. F.; Arce. A. (2017). Applying Value Stream Mapping in manufacturing: a systematic literature review, IFAC-PapersOnLine, Vol. 50, No. 1, 1075-1086, doi:10.1016/ j.ifacol.2017.08.385

[8] Koch, C.; Lödding, H. (2014). Requirements for a Value Stream Mapping in Make-To-Order Environments, Grabot, B.; Vallespir, B.; Gomes, S.; Bouras, A.; Kiritsis, D. (Eds.), Advances in Production Management Systems: Innovative and Knowledge-Based Production Management in a Global-Local World, Springer, Berlin, 391-398, doi:10.1007/978-3-662-44733-8 49

[9] Thomassen, M. K.; Alfnes, E.; Gran, E. (2015). A New Value Stream Mapping Approach for Engineer-to-Order Production Systems, Umeda, S.; Nakano, M.; Mizuyama, H.; Hibino, H.; Kiritsis, D.; von Cieminski, G. (Eds.), Advances in Production Management Systems: Innovative Production Management Towards Sustainable Growth, Springer, Cham, 207-214, doi: 10.1007/978-3-319-22759-7_24

[10] Murat Tabanli, R.; Ertay, T. (2013). Value stream mapping and benefit-cost analysis application for value visibility of a pilot project on RFID investment integrated to a manual production control system - a case study, The International Journal of Advanced Manufacturing Technology, Vol. 66, No. 5-8, 987-1002, doi:10.1007/s00170-012-4383-x

[11] Sunk, A.; Sihn, W.; Kuhlang, P. (2015). Improving productivity by deriving and defining target conditions in the value stream of packing, Transactions of FAMENA, Vol. 39, No. 3, 35-46

[12] Xie, Y.; Peng, Q. (2012). Integration of value stream mapping and agent-based modeling for OR improvement, Business Process Management Journal, Vol. 18, No. 4, 585-599, doi: $10.1108 / 14637151211253747$

[13] Librelato, T. P.; Lacerda, D. P.; Rodrigues, L. H.; Veit, D. R. (2014). A process improvement approach based on the Value Stream Mapping and the Theory of Constraints Thinking Process, Business Process Management Journal, Vol. 20, No. 6, 922-949, doi:10.1108/BPMJ-07-2013$\underline{0098}$

[14] Lasa, I. S.; Laburu, C. O.; de Castro Vila, R. (2008). An evaluation of the value stream mapping tool, Business Process Management Journal, Vol. 14, No. 1, 39-52, doi:10.1108/ 14637150810849391

[15] Chen, Y.; Guo, C.; Li, L. (2015). Optimization of Production System Based on Value Stream Mapping, Zhang, Z.; Shen, Z.; Zhang, J.; Zhang, R. (Eds.), LISS 2014: Proceedings of $4^{\text {th }}$ 
International Conference on Logistics, Informatics and Service Science, Springer, Berlin, 12091214, doi:10.1007/978-3-662-43871-8 175

[16] Centobelli, P.; Cerchione, R.; Murino, T.; Gallo, M. (2016). Layout and material flow optimization in digital factory, International Journal of Simulation Modelling, Vol. 15, No. 2, 223-235, doi:10.2507/IJSIMM15(2)3.327

[17] Badida, M.; Gombar, M.; Maslejova, A.; Sobotova, L.; Kmec, J.; Vagaska, A. (2015). Evaluation of zinc coating quality by statistical methods, Przemysl Chemiczny, Vol. 94, No. 12, 2146-2149, doi:10.15199/62.2015.12.11

[18] Trebuna, P.; Markovic, J.; Kliment, M.; Halcinová, J. (2015). Modeling in Industrial Engineering, $1^{\text {st }}$ edition, TU Kosice, Kosice

[19] Straka, M. (2010). System of distribution logistics of enterprise Alfa, a.s., Acta Montanistica Slovaca, Vol. 15, Special issue 1, 34-43

[20] Straka, M.; Malindzak, D. (2009). Algorithms of capacity balancing of printing machineries for Alfa Foils, a.s. planning system, Acta Montanistica Slovaca, Vol. 14, No. 1, 98-102

[21] Rosova, A. (2010). The system of indicators of distribution logistics, transport logistics and material flow as a tool of controlling in logistics enterprise, Acta Montanistica Slovaca, Vol. 15, Special issue 1, 67-72

[22] Janekova, J.; Fabianova, J.; Izarikova, G.; Onofrejova, D.; Kovac, J. (2018). Product mix optimization based on Monte Carlo simulation: a case study, International Journal of Simulation Modelling, Vol. 17, No. 2, 295-307, doi:10.2507/IJSIMM17(2)436

[23] Straka, M.; Malindzakova, M.; Trebuna, P.; Rosova, A.; Pekarcikova, M.; Fill, M. (2017). Application of EXTENDSIM for improvement of production logistics' efficiency, International Journal of Simulation Modelling, Vol. 16, No. 3, 422-434, doi:10.2507/IJSIMM16(3)5.384

[24] Straka,M.; Lenort, R.; Khouri, S.; Feliks, J. (2018). Design of large-scale logistics systems using computer simulation hierarchic structure, International Journal of Simulation Modelling, Vol. 17, No. 1, 105-118, doi:10.2507/IJSIMM17(1)422

[25] Tecnomatix, from http://www.sova.sk/sk/produkty/tecnomatix, accessed on 16-01-2016

[26] Pekarcikova, M.; Trebuna, P.; Markovic, J. (2015). Simulation as part of industrial practice, Acta Logistica, Vol. 2, No. 2, 5-8, doi:10.22306/al.v2i2.36

[27] Bin Ali, N.; Petersen, K.; Nicolau de Franca, B. B. (2015). Evaluation of simulation-assisted value stream mapping for software product development: two industrial cases, Information and Software Technology, Vol. 68, 45-61, doi:10.1016/j.infsof.2015.08.005

[28] Lenort, R.; Klepek, R.; Samolejova, A. (2012). Heuristic algorithm for planning and scheduling of forged pieces heat treatment, Metalurgija, Vol. 51, No. 2, 225-228

[29] The Goodyear Tire \& Rubber Company. Reinforced materials in rubber products, from https://www.tut.fi/ms/muo/vert/10_reinforcing_materials/, accessed on 08-04-2018

[30] Pekarcikova, M.; Trebuna, P.; Filo, M. (2014). Methodology for classification of material items by analysis $\mathrm{ABC} / \mathrm{XYZ}$ and the creation of the material portfolio, Applied Mechanics and Materials, Vol. 611, 358-365, doi:10.4028/www.scientific.net/AMM.611.358 